\title{
The Articulation of Moderate Islam among Muslim Students
} A Case Study in State Islamic University of Malang

\author{
Benny Afwadzi ${ }^{1, *}$ Miski Miski ${ }^{2}$ \\ ${ }^{1}$ Faculty of Tarbiyah and Teacher Training, Universitas Islam Negeri Maulana Malik Ibrahim Malang, Indonesia \\ ${ }^{2}$ Faculty of Syariah, Universitas Islam Negeri Maulana Malik Ibrahim Malang, Indonesia \\ ${ }^{*}$ Corresponding Author. Email: afwadzi@pai.uin-malang.ac.id
}

\begin{abstract}
This article aims to explain the articulation of moderate Islam among Muslim students. This research finds its significance in, on the one hand, the existence of previous studies confirming that a myriad of radicalism and terrorism were conducted by students, while, on the other hand, moderate Islamic behavior is regarded as a good solution for preventing radicalism and terrorism. Three aspects appear to be the focus of this research, namely: first, the conception of moderate Islam; second, the approval and rejection of moderate Islam; and third, the factor of the articulation of moderate Islam. This research takes State Islamic University of Malang, Indonesia, as the primary data source by giving unstructured interviews towards 12 of its students coming from different academic backgrounds (natural sciences, social-humanities, and religious sciences). Meanwhile, secondary sources are collected from either books, articles, or other findings concerning topics related to moderate Islam and the act of radicalism among students. The content analysis and critical hermeneutics are the main analysis tools in this research. This study finds that the articulation of moderate Islam has existed among students. In general, students understand the term "moderate Islam" as "the middle position" of Islam that is articulated with a wide variety of arguments. There is a rejection against this terminology among students of social-humanity (psychology), hence contradicts a common opinion stating that students of social-humanity are more preventable from radicalism and terrorism than those who take natural sciences programs. Furthermore, we will elaborate on five main factors leading to the articulation of moderate Islam among Muslim students: first, whether there is an impact of being a moderate Islamic organization member or not; second, the formal and informal education; third, the heterogeneous or homogeneous residential demography in which students live; fourth, the social media accounts followed, and fifth, the literature they read.
\end{abstract}

Keywords: Articulation, Moderate Islam, Natural Sciences, Social-Humanity, Religion.

\section{INTRODUCTION}

There is no rigid and final conception of moderate Islam since all individuals have their subjective interpretation of this word [1]-[5]. This situation has led to many rejections against the term [6]. The basis of their refusal comes from an idea that moderate Islam cannot be a representative of the so-called ' $k \overline{a f f a h}$ ' (the complete) Islam as their proponents are trapped in spiritless Religious practices as well as the Western hegemony over Islam [7].

Based on some research findings and cases, the opposite is true since the idea of promoting moderate Islam becomes pivotal in many nations, including
Saudi Arabia whose ideology is conservative and fundamentalism [8]. Moreover, the conception of moderate Islam appears to be significant to be unveiled more deeply. This is down to the fact that, on the one hand, some researches have affirmed several massive terrors and radicalism among students both in public universities and Islamic universities [9]-[11], while, on the other hand, the idea of moderate Islam is considered as a powerful solution to prevent students from the act of radicalism and terrorism [12]-[16].

This article takes Maulana Malik Ibrahim State Islamic University of Malang, Indonesia, as the main research object due to some reasons: first, even 
though the intense inter-religious dialogues had been continuously held, the rate of violation against religious freedom between students in Malang remains high [17]; second, universities in Malang (including State Islamic University of Malang) have the great potency of producing the seeds of radicalism and terrorism among students due to the massive movement of people in and out of the city; third, State Islamic University of Malang has the largest number of foreign students compared to other State Islamic Universities (PTKIN) in Indonesia; and fourth, there are a great number of terrorist arrests in Malang region [18].

This article is centered on three aspects, namely: first, the conception of moderate Islam among Muslim students; second, their approval and rejection against this terminology; and third, the factor of the articulation of moderate Islam. The two former aspects are explained based on students' academic fields, namely natural sciences, social-humanity, and religion. Furthermore, while most of the recent findings merely examined the interpretation of moderate Islam that is performed by public figures, organizations, and educational institutions, and they constructed the moderate Islam and its correlation with Islamic principles theoretically and practically [19]-[25], this article, however, aims to focus on unveiling the moderate Islam understanding among students based on their academic fields which never been found in previous researches. Besides, the factor of the articulation of moderate Islam will also be the field of this study to create the basis of the contraradicalism movement in Indonesia. Examining the common belief that the students of natural sciences, for their rigid and binary mode of thought, are more susceptible to get involved with the acts of radicalism and terrorism compared to those of the socialhumanity and religion, for their critical thinking, will be also the objective of this research.

\section{RESEARCH METHODS}

This article uses a qualitative method with the phenomenological approach that obtains data from depth interviews with Muslim students with a variety of religious ideologies in State Islamic University of Malang. The selection of informants is based on a qualitative principle through which a total of 12 students from different academic fields, namely natural sciences, social-humanity, and religion (4 students for each field). Gender is also taken into consideration in which half of the total informants are males while another half comes from the opposite sex. It is estimated that this method will lead to obtaining more comprehensive data. In order to secure informants' privacy, their names will not be unveiled (the information related to informants is attached in Table 1).

The primary data comes from an unstructured interview with 12 students whose answers will lead to a more comprehensive understanding of the articulation of moderate Islam among students. However, due to the pandemic situation, the process of the interview will adjust with the informant's circumstances. When possible, the interview would be conducted in person; otherwise, an online platform would be preferred. Additionally, secondary data comes from a variety of books, journals, and findings that have correlations with the issue of moderate Islam and radicalism among students.

To produce balanced and honest research, data source triangulation and focus group discussion will be conducted. Meanwhile, the data analysis will utilize content analysis which stands on objective data (first and second focus) [26], [27]; and it will use critical hermeneutics as the tool to reveal the factor of articulation (third focus) [28], [29].

Table 1 Research informans

\begin{tabular}{|l|l|l|l|l|}
\hline No. & Character & \multicolumn{1}{|c|}{ Program } & Age & Symbol \\
\hline \hline 1. & & Pharmacy & $21 / \mathrm{M}$ & NS1 \\
\hline \hline 2. & Natural & Mathematics Edu & $21 / \mathrm{M}$ & NS2 \\
\hline \hline 3. & Sciences & Mathematics & $21 / \mathrm{F}$ & NS3 \\
\hline \hline 4. & & Architecture & $21 / \mathrm{F}$ & NS4 \\
\hline \hline 5. & & Arabic Language & $25 / \mathrm{M}$ & SH1 \\
\hline \hline 6. & Social- & Management & $21 / \mathrm{M}$ & SH2 \\
\hline \hline 7. & Humanities & Psychology & $21 / \mathrm{F}$ & SH3 \\
\hline \hline 8. & & Arabic Language & $24 / \mathrm{F}$ & SH4 \\
\hline \hline 9. & & Islamic Edu & $21 / \mathrm{M}$ & RS1 \\
\hline \hline 10. & Religious & Quranic Sciences & $20 / \mathrm{M}$ & RS2 \\
\hline \hline 11. & Sciences & $\begin{array}{l}\text { Islamic Family } \\
\text { Law }\end{array}$ & $22 / \mathrm{F}$ & RS3 \\
\hline \hline 12. & & Quranic Sciences & $21 / \mathrm{F}$ & RS4 \\
\hline
\end{tabular}

\section{RESULT AND DISCUSSION}

\subsection{Natural Sciences Programs}

Concerning the conception of moderate Islam, students of natural sciences programs are aware that the term moderate Islam means the balanced position in Islam. In other words, they view moderate Islam as opposes both radicalism and extremism. In addition, those who implement moderate Islam should behave equitably, adjust to mutable circumstances and produce a proportional tolerance among citizens. One interlocutor (NS3) explained that moderate Islam 
means a balanced Islam that opposes extreme ideologies. Referring to one of the respected figures from Nahdlatul Ulama (NU), Musthofa Bisri, he maintains that moderate Islam is Islam itself.

In this regard, another interlocutor (NS4) explained the following,

"Moderate Islam is an ideology that contradicts both radicalism and terrorism. In other words, moderate Islam is an ideology that is able to adapt to any situation around the world. Even though there are differences between the historical and the current Islam, that is because the situation has changed, and Islam should adjust. Some people blindly perceive a particular teaching, such as warfare during the lifetime of the Prophet Muhammad against the infidels; but in the current context, let alone in Indonesia, warfare is not allowed, for we all have the same right to live as the citizens. Nevertheless, some people perceive this blindly, hence acting wrongfully, such as bomb attacks or others that negatively affected innocent people. Moderate Muslims are the ones who oppose this extreme ideology."

NS1 explicitly explained that the concept of moderate Islam is the implementation of five principles of Pancasila, especially the principle of tolerance. He said,

"Moderate Islam is Islam that proportionally implements the principle of tolerance, since, in our country, it is pivotal for us to implement the principle of tolerance correctly. To be precise, as we all live under the constitution of Pancasila, we ought to honor and tolerate non-Muslims. Therefore, not only should we honor our Muslim brothers and sisters, but we also have the responsibility to do the same towards nonMuslims because we all live in a multicultural nation. In short, it can be concluded that moderate Islam is Islam that follows the principles of Pancasila."

NS2 was in line with the above statement as he said that moderate Islam is Islam that accepts the existence of other religions, and, at the same time, recognizes the internal disagreements among its adherents without discrediting one from another. According to him, flexibility and adaptation are the typical characters of moderate Islam in social interaction, while in terms of worship we should follow what we perceive as correct

At this point, it can be seen that interlocutors from natural sciences programs share their acceptance of the terminology of moderate Islam. The key point of their acceptance is that the implementation of moderate Islam within societies would maintain mutual social respect and tolerance. It is undeniable that tolerance is significantly essential in Indonesia for it is a country resided by citizens of wide diversities and the process of its establishment went through consensus between heterogenous founding fathers. Besides, the concept of moderate Islam is likely to create harmony between societies as it stimulates people's social sensitivity and tolerance. NS2 gave a further explanation,

"I agree with the concept of moderate Islam because in practicing religious doctrines we also need social belief. This social belief should exist within societies in order to implement Islam as rahmatan lil 'alamin. It is undeniable that the practice of moderate Islam will lead to a harmonious relationship between people because with it people commonly pursue being tolerant of each other."

In the same tone as the previous, NS1 said,

"Regarding the concepts or the figures proposing moderate Islam, I see myself in agreement with them, because with it, Islam appears neither to be radical/extreme nor liberal. For this reason, Muslims would maintain their worships, without insisting on its formal implementation in the country, because we live with non-Muslims in a country that has a permanent agreement that obligates its citizens to live harmoniously. Based on this argument, the concept of moderate Islam should be implemented."

Another argument appropriated a normative principle stating that Islam is a balanced religion (wasatiyah) as the principle of moderate Islam. NS3 states that Islam is a measurable and not excessive religion as represented by the Qur'ān, the sunna, and the authoritative $u l a m \bar{a}^{\prime}$. Muslims, in general, are in fact practice moderate Islam.

\subsection{Social Humanities Programs}

The next opinion about the concept of moderate Islam comes from social-humanity students. Having similar ideas with natural sciences students, students in this field also argue that moderate Islam means a balanced Islam (the middle position). They believe that moderate Islam is Islam that is not rigid, flexible, and tolerant. It is worthy of attention that tolerance is the term that was mentioned by all interlocutors in this field. Even though open-minded is one of the basic features of moderate Islam, it opposes extreme attitudes (right or left) and moderate people have sturdy beliefs on their religion. One interlocutor, SH4, states that moderate Islam is Islam that is flexible and rejects fundamentalism and radicalism. In short, the position of moderate Islam is between radicalism and liberalism. It prioritizes the benefits 
for the society because of their comprehensive view about various aspects of Islam.

Furthermore, SH1 defined tolerance as the manifestation of moderate Islam. He said,

"Moderate Islam is Islam that can tolerate people with different beliefs and can balance the worldly life and the hereafter. In addition, someone applying moderate ideology will be able to adjust with any circumstance without leaving his or her basic belief."

Based on the above statement, we can conclude that moderate Islam is an open and inclusive ideology that affirms the development of modernization. Besides, moderate Islam is an ideology that can adjust with renewals and it leads to harmony (mașlahat) within societies without disobeying Islamic principles and limitations. Interestingly, SH2 linked tolerance and the concept of tawhìd as the core principle of Islam. The informant said that every Muslim has to tolerate other beliefs and religions. On top of that, moderate Islam is located in the middle position (between right and left extremists) as mentioned in QS. Al-Baqarah (2): 143.

A slightly different opinion was mentioned by SH3 who, although respecting the tolerance, is still obstructed by the act of apostate as well as the ignorance of it. Moreover, she perceived this behavior as a deviation that should be avoided in applying moderate Islam. More comprehensively she said,

"According to my own opinion as well as some resources about moderate Islam that I have read so far, it can be concluded that this term means a middle position in Islam. The middle position here means that a moderate Muslim should not force others to follow his view and should not affirm any deviation in religion. What I understand about moderate Islam is that it is comprised of justice, respect, tolerance, and strong conviction in rejecting any deviance. Hence, the middle position of moderate Islam means not to force others to follow our belief as well as not to tolerate any deviation in Islam such as apostate. As a person who understands the concept of moderate, we should not underestimate or permit anyone to do apostate."

The majority of students support the terminology of moderate Islam while the minority of them ignore it. Those who accept moderate Islam terminology believe that this concept will create harmony and it will alleviate conflicts within societies when everyone has different backgrounds. This is in line with what $\mathrm{SH} 2$ said,
"My reason for accepting the concept of moderate Islam is down to the fact that this concept can create harmony, and prevent conflicts and ex-communication among people. On top of that, varieties and differences between people can be the factors of harmony when the concept of moderate Islam is implemented."

This opinion was affirmed by SH4 who said,

"As a Muslim student living in a $\mathrm{Z}$ generation, I myself appear to be happier since there is an increasing number of people who ignore both left and right extreme ideologies. Moderate Islam finds its significance since we need to adapt and communicate with other people whose beliefs are different from us; consequently, standing in the middle should be our priority."

The acceptance of the concept of moderate Islam was also shown by SH1. This is because, according to him, any ignorance against the concept of moderate Islam means a conflict against the sanad derived from his teachers. SH1 believes that the concept of moderate Islam consisted in the Constitution of Medina is proof that Prophet Muhammad has implemented moderate Islam during his life. Based on this, he argues that the next generations have to follow what the Prophet has done. Furthermore, he explained that Islam Nusantara has also followed the concept of Islam applied in Arabia. However, Muslims in Nusantara implemented the Islamic doctrines and principles by adjusting with local cultures. For example, while Muslims in Arab gave palm fruit to others as their zakah since they consumed it as a staple, Muslims in Nusantara took the rice for giving their zakah because this is the food they consumed on daily basis.

Among social-humanity students, there was someone who opposed the concept of moderate Islam. She argued that the basic principle of Islam is about moderation; so that there is no need to use the term of moderation in Islam. By adding the new concept of moderate Islam, she said, it means that we perceive Islam as a religion that is free from moderation in its basic principles, which, can imply the classification of Muslims.

This opinion was confirmed by SH3, she said,

"Why should we create the term moderate Islam? Has not this term existed since the life of Prophet Muhammad? This religion is rahmatan lil 'alamin that guides all human beings to a better life. In the Prophet Muhammad's era, Islam became a guide for people; neither does it force people to follow its principles nor doing any violation to force them to turn into Islam." 
Based on the aforementioned statement, it can be noticed that the value of moderate Islam ought to be implemented within the society. The main objective of this implementation is to prevent any potential conflict caused by the difference in social status, religion, or background. Nevertheless, it should be taken into consideration that the value of moderation has existed in basic principles of Islam; hence, we do not need to create the term moderate Islam and other meaningless terms. More astonishingly, this informant perceives that the term moderate Islam is the representation of radical Islam,

"In my opinion, some people have tried to hide the term of liberal Islam by replacing it with the term moderate Islam. I got the information from the news informing that there is a group of Muslim liberals introducing themselves as moderate Muslim who is free from Islam deviations."

These statements contradict the popular belief saying that natural sciences students are more susceptible to the act of radicalism than socialhumanity students [9], [30]. All programs have the potency to lead the students to do radicalism and terrorism when they are not urged to learn about representative moderate Islam. This potency can be proven by an act of terrorism (book bomb, 2011) done by several alumni who ever studied at Islamic Education, Philosophy, and Arabic Language program in State Islamic University of Syarif Hidayatullah Jakarta [11].

\subsection{Religious Sciences Programs}

With a little different approach, students of the religious sciences program have a similar opinion with those from natural sciences and social-humanity stating that moderate Islam is a balanced religion that stands in the middle position. RS1 explains that moderate Islam consists of three meanings, namely tawassut, tawāzun, dan $i$ 'tidāl. Tawassut means that Islam does not lean either towards the left position which leads someone to liberalism or towards the right position which leads someone to radicalism. Tawāzun means a balance Islam that is not too strict or too lenient. Meanwhile, i'tidāl means an attitude through which someone is always fair in his or her social interaction. Furthermore, he explained,

"The moderate Islam is an attitude standing between liberalism and radicalism. This means that a moderate Muslim is able to comprehend the principles of Islam without being trapped with left or right extreme positions. In addition, a moderate Muslim has good capability to adapt with any circumstance."
Having a similar opinion with RS1, RS2 explained that the term moderate Islam was derived from the word wasatiyyah meaning the middle position in the Arabic language. This informant urged that a Muslim student should not follow any extreme left or right position. Actually, they are not prohibited to learn about those extreme principles; however, they should still stand with their moderate position. Moderate Muslims, he argued, are those who prevent themselves from prioritizing logic to dalīl and prevent themselves from being too fanatical about dalīl. In short, moderation is taking the two perspectives without leaning to any one of them.

Another informant, RS3, illustrated Islam from the perspective of women's Muslim fashion (the wearing of veil),

"Moderate Islam is a balance Islam which does not lean to left or right extreme positions, and it can adapt with the local culture. Take the style of fashion applied by Nahdlatul Ulama students in Pesantren as an example. The core principles of their fashion style are politeness, syar'an [obeying shari'ah], and 'adatan [adjusting with the local culture]. While the radical ideology obligates female students to wear the veil, the liberal one permits them to wear any style they want [without limitation]. In contrast, a moderate female student will wear a fashion that is adjustable with the local culture and the shari'ah without a need to wear a veil."

RS4 explained that moderate Islam is an Islam that leads its believers to fairness. A moderate Islam is not a sect; it is the core principle of Islam that also obligates its believers to have a strong attitude. For example, when someone has children, he or she will give them money proportionally based on their ages; the older they are, the more money they will obtain. Moderation also correlates with fairness. In other words, when moderate Muslims behave fairly, they will not easily be trapped into the right or the left extreme positions due to their fair ability to assess which one is correct or false. Also, no one can force others to accept Islam. It is their right to choose which religion they want to believe in (either Islam or Buddha or Christian or other religions).

It can be concluded that students of the religious sciences program in State Islamic University of Malang agree that moderate Islam means an Islam which acts as an intermediary between liberalism and radicalism and it can combine between logic and dalīl. Also, moderate Islam becomes a concept which prioritizes objectivity in solving a problem and it has the capability to adjust with local cultures. The concept of moderate Islam explained by religious sciences students is likely more scientific than the 
explanation given by students in natural sciences and social-humanities programs. This is down to the fact that the students of the religious sciences program linked their arguments to the most updated discourse in this era.

Meanwhile, the main factor of their acceptance and affirmation towards the concept of moderate Islam is that this concept has been implemented by the Prophet Muhammad and his companions. This is proven by the existence of the constitution of Medina as well as the style of da'wah applied by Wali Songo consisting of the principles of moderation. This is explained by RS1 saying,

"I do agree with the concept of moderate Islam because this is the concept that our Prophet Muhammad had implemented during his life, and this is proven by the existence of the constitution of Medina. At the time, there were three different religions embraced by people in Madinah, namely Christian, Jewish, and Samawi. Before the coming of Islam, they had fought each other and contributed to intense conflicts. However, these splits were successfully solved by Prophet Muhammad and his companions by inviting those non-Muslim people to implement the principles of moderation that consisted in the Constitution of Medina. In my opinion, the basic value of moderation in the Constitution of Madinah is that when declaring this constitution, Prophet Muhammad involved Auz and Khazraj sects. These two sects discussed with the Prophet the content of the Madinah constitution and they agreed to declare it. This method was also applied by Wali Songo when they arranged the conception of moderate Islam adjusting with the local cultures in Java Island.”

A similar opinion was proposed by RS4 who explained,

"The implementation of moderation had been done during the first emergence of Islam; hence, it is the correct attitude when we try to behave moderately. By implementing the concept of moderate Islam, a sense of tolerance will emerge in our hearts. This is extremely crucial for us who live in a country that consists of a variety of islands, sects, and cultures; so that I do accept the concept of moderate Islam."

Therefore, these two informants agreed that the value of moderate Islam has its origin from the life of Prophet Muhammad as it was stated in the chapters of the constitution of Medina. Of the moderation, principles are the freedom of implementing religious principles and giving opinions as well as the guarantee of property security. This means that moderation is a concept introduced by the prophet so that all Muslims should apply it in every aspect of their life.

Furthermore, RS2's acceptance of the concept of moderate Islam is due to its position which is between the two extreme perspectives. When someone leans to one of the two extreme perspectives, it means that he or she contradicts the basic principle of Islam that is moderate. Nevertheless, every Muslim is still encouraged to learn about the two contradictive perspectives such as the sect of Mu'tazilah who has an extreme principle in the use of logic and the sect of Wahabiyah who has an extreme principle in the use of dalil. It is permissible for Muslims to absorb any information regarding those two sects, but they should stand with their moderate attitude in implementing Islamic principles.

\subsection{Why Are They Different?}

Even though the students of State Islamic University of Malang have the same basic understanding of the concept of moderate Islam, the arguments and approaches they used to explain their thoughts are different. Regarding their group affiliation, some students affiliate with the traditional group of Nahdlatul Ulama (NU) while some others affiliate with the modern group of Muhammadiyah. Meanwhile, few of them claim that they affiliate to the blend of both groups. If we examine these statements more deeply, we can unveil some factors that stimulate the appearance of the articulation of moderate Islam as explained previously.

First, whether the affiliation towards a specific organization (Nahdlatul Ulama or Muhammadiyah) will give a significant impact or not. The impact of this can be acknowledged from the statement of SH3 stating that the term moderate Islam is a representation of liberalism. After being asked about her group affiliation, this informant admitted that she did not recognize both Nahdlatul Ulama and Muhammadiyyah groups beforehand although her religious practices are relatively similar to Nahdlatul Ulama's tradition. This informant was firm on her belief that there is no need to affiliate with any religious organization to be a real Muslim. Based on this opinion, it can be concluded that someone's affiliation towards any religious organization or group can construct his or her understanding and acceptance towards the concept of moderate Islam. As long as the students never know about the variety of Muslim typologies and religious organizations, they will never accept the term moderate Islam. In 
short, they perceive Islam as a singular religion and it should not be split.

Something needed to be taken into consideration regarding this type of student is that she is susceptible to being persuaded to accept radicalism. She tends to easily accept any information shared in social media without understanding the real identity of each organization's principle. Even though she claims that she has received some recommendations regarding credible social media accounts from their lecturers and friends, she still rejects the concept of moderate Islam. She also informed about the resources she had read which form her ignorance against moderate Islam,

"The fact that I absorb this information from the internet is something I cannot deny. However, I have tried to filter and analyze any information I obtain from the internet before I accept or reject it. And I think there are both trusted and untrusted blogs and websites. I usually get trusted websites from friends who understand religious principles. Besides, some of my lecturers who have a high-level understanding of Islamic principles have also informed me of some websites consisting of trusted articles whose contents do not contradict our common religious understanding. Not only do I look for the websites that consist of Qur'an verses, but I also look for those which refer to the hadith. Therefore, as long as they are supported by Qur'anic texts and hadith, they can be trusted."

Meanwhile, the students who have contradicting opinions with the above student admit that they affiliate with Nahdlatul Ulama, Muhammadiyah, or both of them. They based their opinion on the typical culture of moderation applied by both organizations. Although there are frictions within them, this does not change the path of moderation held by NU and Muhammadiyah [19], [31]-[34]. SH2 said that his understanding of the concept of moderation comes from the explanation he obtained from his family who affiliated with Nahdhaltul Ulama and urged him to take his education in a Pesantren established by Nahdlatul Ulama. This is the reason why the informant believes that Nahdlatul Ulama is an organization that proposes moderate Islam. On top of that, he was taught by his family that it is essential to respect other's opinion even though it contradicts our personal opinion. He was also inspired by a statement from one of Nahdlatul Ulama figure called Musthofa Bisri or Gus Mus who said, "Not implementing moderation means it is not the part of Islam".

A similar story was experienced by RS3 who claimed that the first time she got the explanation about moderate Islam was when she joined an autonomous organization of Nahdlatul Ulama. The informant who proposes an idea that moderation in women's fashion is not wearing veils often refers to quotes from Nahdlatul Ulama figures. She said,

"The first time I heard about the term moderate Islam was when I got involved in an organization called IPPNU. Besides, I also learned about this concept from Abah Yai Marzuki Mustamar (the leader of PWNU in East Java) who explained this term with understandable and pleasant narratives. Meanwhile, some lecturers whom I learned about moderate Islam to based their opinion to the sanad they inherited from Nahdlatul Ulama figures."

Second, whether the type of education is formal or informal. There is no specific subject concerning the concept of moderate Islam in the formal education of State Islamic University of Malang. This is slightly different from what is applied in both Nahdlatul Ulama and Muhammadiyah's universities. Nahdlatul Ulama universities provide a subject called Aswaja dan Ke-NU-an which concerns Nahdlatul Ulama principles while Muhammadiyah universities provide a subject called Al-Islam dan Kemuhammadiyahan that specify thoughts related to Muhammadiyah principles [35]. However, said the students, some lectures occasionally insert the concept of moderate Islam in their class, especially those who teach about religion and civics subjects. Also, even though some lecturers do not explicitly state the term "moderate Islam" in their talks, some students can understand that the hidden meaning of their explanation is moderate Islam itself.

Another important thing is that the characteristic of each department also gives a significant impact on students' understanding of moderate Islam. The students of religious sciences programs obtain much more explanations about moderate Islam from their lectures than those who are from social-humanity and natural sciences programs. Some of them argue that the lack of explanation about moderate Islam is because of the disconnection between their program and the term moderate Islam itself. Nevertheless, their understanding of the concept of moderate Islam was influenced by some external factors that form their paradigms. NS3 admits that since she takes his education in the Faculty of Science and Technology, her understanding of religious principles appears to be very limited because the concept of moderate Islam is rarely introduced in her subjects. A similar argument was also expressed by NS4 whose understanding of moderate Islam was obtained from some discussions in the class. One of which was a discussion about whether it is allowed to get 
vaccinated from the liquid that contains pig enzymes or not. Although the term moderate Islam was not mentioned explicitly in this discussion, the method of producing a conclusion takes the value of moderation.

A contradictive experience was introduced by the students of the religious department admitting that although they do not have any specific subject concerning the concept of moderate Islam, they still obtain an abundance of information about this term. RS1 who explored three core principles of moderate Islam (tawassut, tawazun, and I'tidal) verified that almost $80 \%$ of all lecturers in his department introduce and teach the concept of moderate Islam in the class. Furthermore, he explained the way his lectures use in teaching the students about moderate Islam, he said,

\footnotetext{
"There are a number of lecturers introducing me about the concept of moderate Islam, such as Lecture A, Lecture B, and Lecture C. Since the Lecture B who teaches the subject of Theosophy is used to explain the diversity of beliefs in Islam so that she often relates it with the concept of moderate Islam. For example, when she explained about the discrimination against Shi'a Muslims in Madura, she said that this case is caused by Madura people's extreme fanaticism towards their kyiai (Muslim figure) who said, "There is no Shi'a adherent is permitted to live in this village". According to this lecturer, their arbitrary attitude against Shi'a adherents is a form of intolerance because it takes away another Muslim's rights. From this humiliating phenomenon Lecture B insisted that let alone with non-Muslims, with fellow Muslims we still often fight against each other due to the taqlid which leads us to have no conviction. That is why some groups claim that they have the most correct principles while others have the wrong ones."
}

RS3 explained the same experience that almost $80 \%$ of her lectures teach about moderate Islam in the class. This percentage is in line with RS1's statement even though they were interviewed separately. There is indeed no specific subject about moderate Islam; however, regular discussion introducing the concept of Islam has been conducted in the class such as the explanation of hadith and its sanad which are often interpreted using the concept of moderate Islam.

Meanwhile, the non-formal type of education in Pesantren also gives significant contribution towards students' articulation of moderate Islam. This is supported by the situation in which the new students of State Islamic University of Malang are obligated to stay at a Pesantren (university's ma'had) during their first year. SH4 as the informant who defined moderate Islam as an Islam that opposes fundamentalism and radicalism admitted that she has taken his education in a salaf Pesantren where he absorbed the information about moderate Islam. She said,

"The reason why I am really familiar with the concept of moderate Islam is that I come from a family who is firm on religious principles and values. Besides, since my childhood, I was taught a bunch of salaf's traditional books (kutub) in a Pesantren of salaf. Based on those books, I find that moderate Islam can lead us to harmony and peace."

Third, whether the type of accommodation is heterogeneous or homogeneous. There is no doubt that the type of accommodation can be a significant factor in the articulation of moderate Islam among students. This is down to the fact that the more heterogeneous the student's interaction is, the more moderate they are. Due to this heterogeneous circumstance, the meaning of moderate Islam can be embedded in students' life as they can learn directly from societies living around them. This is what was mentioned by NS4 stating that a plural circumstance determines someone's comprehension of moderate Islam.

A similar statement was also declared by RS1, he said,

"My understanding of moderate Islam was derived from various aspects, including literatures and experiences. I live in a society that consists of various religions such as Hinduism, Buddhism, Christianity, and Kejawen Islam. The unique culture of this heterogeneous circumstance is that when Hinduism adherents celebrate their holiest holiday, Muslims and Christians will visit their houses and vice versa. This is the realization of the concept of moderation in my surroundings."

Fourth is the choice of social media. There is no doubt that, in this era, social media becomes the crucial factor determining students' articulation of moderate Islam. Most of the informants claim that the information they absorb from social media has given immense influence to their paradigm of the concept of moderation [36], [37]. NS2 who defined moderate Islam as an Islam which tolerates both Muslims and non-Muslims admitted that his comprehension of moderate Islam comes from Youtube videos, not from formal education. The channels he often watches related to the concept of moderate Islam are Habib Ja'far Husein, Cak Nun, Yudi Latif's public lectures, Elisa Wahib, or some channels run by a specific religious organization such as KH. Said Aqil 
Siraj and Buya Ma'arif's speeches. Among these channels, there is one statement that the informant finds as the most memorable quote stated by Cak Nun; the quote is, "even though we adhere to different religions, we still live under the same sense of humanity." On top of that, there is a quote from Habib Ja'far Husein who said that congratulating non-muslims regarding their holiest day is actually permissible because our intention is to appreciate others' happiness.

Meanwhile, RS4 admitted that she was intrigued to know about moderate Islam term after it became popular. She said,

\footnotetext{
"Commencing with the information from a friend who continuously told me about the term moderate Islam, I tried to look for as much information as I can from Youtube channels explaining about this term. Besides, when I knew that a teacher who taught me about four sects (madhab) of fiqh referring to various resources also implements the concept of moderate Islam, I realized that this term has opened my perspective about Islam.”
}

Fifth is the literature study that is done by students. In this context, the students analyze a variety of literatures including books and scientific articles that have a correlation with moderate Islam based on their own characteristics. This condition was declared by RS2 who obtained the understanding of moderate Islam from a book written by Quraish Shihab entitled Wasathiyah. This admission is in line with the explanation he gave to me when we interviewed him [24]. The informant argued that the term moderate Islam is derived from the word wasatiyah which means the middle position. This middle position means that a moderate Muslim is someone who clings to the basic principles of moderate Islam and does not lean to any of two extreme perspectives (right or left). Also, a moderate Muslim will not prioritize his logic over the dalìl, and he or she will not behave extremely towards the dalill. In short, it is merely about the balance of logic and dalìl.

\section{CONCLUSION}

This article concludes that there is articulation towards the concept of moderate Islam among Muslim students. Even though they agree that Islam is a religion standing in the middle position, the arguments they declared are diverse. On the other hand, there is a student from social-humanity programs who reject the term moderate Islam as he regards it as the representation of liberal Islam. Based on this finding, the classic belief perceiving that social-humanity students are further from radicalism than those from natural sciences needs to be reviewed. Other findings are related to the factors contributing to the emergence of the articulation towards moderate Islam among students, namely the impact of being an Islamic organization member, the formal or informal style of education, heterogeneous or homogeneous type of accommodation, social media accounts followed, and the study of literature joined.

\section{ACKNOWLEDGMENTS}

This article is our contribution in Litapdimas research program in 2021 entitled "Artikulasi Islam Moderat di Kalangan Mahasiswa Muslim dan Implikasinya terhadap Gerakan Kontra-Radikalisme di Indonesia: Kajian pada Perguruan Tinggi Islam di Malang". Therefore, we thank the Ministry of Religious Affairs and LP2M of State Islamic University of Maulana Malik Ibrahim Malang who conducted this program.

\section{REFERENCES}

[1] M. N. M. Osman and A. Arosoaie, "Jihad in the Bastion of 'Moderation': Understanding the Threat of ISIS in Malaysia," Asian Secur., vol. 16, no. 1, pp. 1-14, 2020, doi: 10.1080/14799855.2018.1470508.

[2] R. Ab Rashid et al., "Conceptualizing the Characteristics of Moderate Muslims: a Systematic Review," Soc. Identities J. Study Race, Nation, Cult., pp. 1-13, 2020, doi: $10.1080 / 13504630.2020 .1814720$.

[3] B. Afwadzi and M. Miski, Islam Moderat dan Shī'ah Zaydiyah: Kontribusi Pemikiran Hadis Muhammad ibn Ismā'ìl al-Șan'ānī bagi Moderasi Islam di Indonesia. Malang: UIN-Maliki Press, 2020.

[4] A. R. Arifianto, "Islamic Campus Preaching Organizations in Indonesia: Promoters of Moderation or Radicalism?," Asian Secur., vol. 15 , no. 3 , pp. 323-342, 2019, doi: 10.1080/14799855.2018.1461086.

[5] N. ter Laan, "Musical negotiations of a 'moderate' versus a 'radical' Islam in Morocco: dissonance and the sonic among vocal performers of Islam-inspired music," Religion, vol. 51, no. 2, pp. 214-236, 2021, doi: 10.1080/0048721X.2021.1865602.

[6] D. Pipes, “There Are No Moderates: Dealing 
with Fundamentalist Islam," Natl. Interes., no. 41 , pp. $48-57,1995$.

[7] M. Hilmy, "Whither Indonesia's Islamic Moderatism?: A Reexamination on the Moderate Vision of Muhammadiyah and NU," J. Indones. Islam, vol. 7, no. 1, pp. 2448, 2013, doi: 10.15642/JIIS.2013.7.1.24-48.

[8] S. Athanasoulia, "From 'Soft' to 'Hard' to 'Moderate': Islam in the Dilemmas of Post2011 Saudi Foreign Policy," Religions, vol. 11, no. 4, pp. 1-18, 2020, doi: 10.3390/rel11040211.

[9] M. Sirry, "Muslim Student Radicalism and Self-Deradicalization in Indonesia," Islam Christ. Relations, vol. 31, no. 2, pp. 241-260, 2020, doi: 10.1080/09596410.2020.1770665.

[10] H. Beni and A. Rachman, "Media Sosial dan Radikalisme Mahasiswa," ORASI J. Dakwah dan Komun., vol. 10, no. 2, pp. 191-203, 2019, doi: 10.24235/orasi.v10i2.5368.

[11] M. Z. Mubarak, "Dari Semangat Islam Menuju Sikap Radikal: Pemikiran dan Perilaku Keberagamaan Mahasiswa UIN Syarif Hidayatullah Jakarta," J. Maarif Arus Pemikirian Islam dan Sos., vol. 8, no. 1, pp. 192-217, 2013.

[12] N. Salamah, M. A. Nugroho, and P. Nugroho, "Upaya Menyemai Moderasi Beragama Mahasiswa IAIN Kudus melalui Paradigma Ilmu Islam Terapan," Quality, vol. 8, no. 2, p. 269, 2020, doi: 10.21043/quality.v8i2.7517.

[13] H. Shifiyuddin, "Konstruksi Ideologis Islam Moderat di Lingkungan Kampus: Studi Kasus Ma'had Al-Jami'ah UIN Sunan Ampel," Fikri J. Kaji. Agama , Sos. dan Budaya, vol. 4, no. 1, pp. 15-30, 2019, doi: 10.25217/jf.v4i1.441.

[14] D. Sadiah, "Strategi Dakwah Penanaman Nilai-nilai Islam dalam Menangkal Paham Radikalisme di Kalangan Mahasiswa," Anida Aktual. Nuansa Ilmu Dakwah, vol. 18, no. 2, pp. 219-238, 2018, doi: 10.15575/anida.v18i2.5064 Strategi.

[15] L. S. Pratama, E. N. Wibowo, Lia Safitriningsih, Juma'iyah, and T. N. Rohmah, "Variasi Pemahaman Keagamaan Mahasiswa IAIN Surakarta," Academica, vol. 1, no. 1, pp. 113-125, 2017.

[16] A. Amirudin, S. P. Nasution, S. Subandi, and D. Lazwardi, "Internalisasi Nilai-Nilai Piil Pesenggiri Dan Islam Moderat dalam Menangkal Paham Radikal pada UKM
Mahasiswa UIN Raden Intan Lampung," AlIdarah J. Kependidikan Islam, vol. 10, no. 2, pp. 256-270, 2020, doi: 10.24042/alidarah.v10i2.7449.

[17] U. Sumbulah, "Islam and Freedom of Religion: Religious Elites Perspectives in Malang, East Java, Indonesia," IOSR J. Humanit. Soc. Sci., vol. 21, no. 6, pp. 95102, 2016, doi: 10.9790/0837-21060895102.

[18] B. Afwadzi, "Membangun Moderasi Beragama di Taman Pendidikan Al-Qur'an dengan Parenting Wasathiyah dan Perpustakaan Qur'ani," Transform. J. Pengabdi. Masy., vol. 16, no. 2, pp. 106-120, 2020, doi: 10.20414/transformasi.v16i2.2647.

[19] J. Menchik, "Moderate Muslims and Democratic Breakdown in Indonesia," Asian Stud. Rev., vol. 43, no. 3, pp. 415-433, 2019, doi: 10.1080/10357823.2019.1627286.

[20] M. Mutawali, "Moderate Islam in Lombok: the Dialectic between Islam and Local Culture," J. Indones. Islam, vol. 10, no. 2, pp. 309-334, 2016, doi: $10.15642 / J I I S .2016 .10 .2 .309-334$.

[21] W. A. Jafar, "Persepsi Masyarakat Kota Bengkulu Terhadap Paham Islam Moderat," MIZANI Wacana Hukum, Ekon. dan Keagamaan, vol. 5, no. 1, pp. 75-92, 2018, doi: 10.29300/mzn.v5i1.1438.

[22] A. Cherney and K. Murphy, "What does it mean to be a moderate Muslim in the war on terror? Muslim interpretations and reactions," Crit. Stud. Terror., vol. 9, no. 2, pp. 159-181, 2016, doi: 10.1080/17539153.2015.1120105.

[23] M. Salik, "Conserving Moderate Islam in Indonesia: An Analysis of Muwafiq's Speech on Online Media," J. Indones. Islam, vol. 13, no. 2, pp. 373-394, 2019, doi: 10.15642/JIIS.2019.13.2.373-394.

[24] M. Q. Shihab, Wasathiyah: Wawasan Islam tentang Moderasi Beragama. Jakarta: Lentera Hati, 2020.

[25] A. Ardiansyah, "Islam Wasaṭ̂yah dalam Perspektif Hadis: Dari Konsep Menuju Aplikasi," Mutawatir J. Keilmuan Tafsir Hadis, vol. 6, no. 2, pp. 232-256, 2016, doi: 10.15642/mutawatir.2016.6.2.232-256.

[26] D. Koufogiannakis, L. Slater, and E. Crumley, "A content analysis of librarianship research," J. Inf. Sci., vol. 30, no. 3, pp. 227239, 2004, doi: 10.1177/0165551504044668. 
[27] M. D. White and E. E. Marsh, "Content analysis: A flexible methodology," Libr. Trends, vol. 55, no. 1, pp. 22-45, 2006, doi: 10.1353/lib.2006.0053.

[28] G. McCaffrey, S. Raffin-Bouchal, and N. J. Moules, "Hermeneutics as research approach: A reappraisal," Int. J. Qual. Methods, vol. 11, no. 3, pp. 214-229, 2012, doi: $10.1177 / 160940691201100303$.

[29] M. Paterson and J. Higgs, "Using Hermeneutics as a Qualitative Research Approach in Professional Practice," Qual. Rep., no. June 2005, 2015, doi: $10.46743 / 2160-3715 / 2005.1853$.

[30] A. Azra, Relevansi Islam Wasathiyah: Dari Melindungi Kampus Hingga Mengaktualisasikan Kesalehan. Jakarta: Kompas Media Nusantara, 2020.

[31] Z. Darajat, "Muhammadiyah dan NU: Penjaga Moderatisme Islam di Indonesia," Hayula Indones. J. Multidiscip. Islam. Stud., vol. 1, no. 1, pp. 79-94, 2017, doi: 10.21009/hayula.001.1.05.

[32] A. N. Burhani, "Lakum dīnukum wa-liya dīnī: the Muhammadiyah's stance towards interfaith relations," Islam Christ. Relations, vol. 22, no. 3, pp. 329-342, 2011, doi: $10.1080 / 09596410.2011 .586512$.
[33] A. N. Burhani, "Al-Tawassut wa-1 I'tidāl: The NU and Moderatism in Indonesian Islam," Asian J. Soc. Sci., vol. 40, pp. 564 $581,2012$.

[34] A. Z. Hamdi, "Radicalizing Indonesian moderate islam from within: The NU-FPI relationship in Bangkalan, Madura," $J$. Indones. Islam, vol. 7, no. 1, pp. 71-95, 2013, doi: 10.15642/JIIS.2013.7.1.71-95.

[35] T. Suharto, "Gagasan Pendidikan Muhammadiyah dan NU Sebagai Potret Pendidikan Islam Moderat di Indonesia," Islam. J. Stud. Keislam., vol. 9, no. 1, pp. 81109, 2014, doi: 10.15642/islamica.2014.9.1.81-109.

[36] I. F. Ghifari, "Radikalisme di Internet," Relig. J. Stud. Agama-Agama dan Lintas Budaya, vol. 1, no. 2, pp. 123-134, 2017, doi: 10.15575/rjsalb.v1i2.1391.

[37] W. Akmaliah, "The demise of moderate Islam: New media, contestation, and reclaiming religious authorities," Indones. J. Islam Muslim Soc., vol. 10, no. 1, pp. 1-24, 2020, doi: 10.18326/ijims.v10i1.1-24. 